\title{
Microvascular alterations in patients with SARS-COV-2 severe pneumonia
}

\author{
Elisa Damiani ${ }^{\dagger}$, Andrea Carsetti ${ }^{\dagger}$, Erika Casarotta, Claudia Scorcella, Roberta Domizi, Erica Adrario \\ and Abele Donati ${ }^{*}$ (1)
}

To the Editor,

Multiple evidences suggest that pulmonary microcirculatory dysfunction may play a key role in the pathogenesis of SARS-COV-2 severe pneumonia.

SARS-COV-2 uses the angiotensin converting enzyme 2 (ACE2) as its receptor [1]. ACE2 normally functions as a negative regulator of the renin-angiotensin system (RAS) [1]. RAS dysregulation leads to increased vascular permeability, inflammation and pneumocyte apoptosis [1]. Pulmonary microvascular leakage may result in lung oedema and impaired lung function.

Severe Coronavirus disease 2019 (COVID-19) is frequently complicated by coagulopathy and markedly elevated D-dimer is associated with poor prognosis [2]. The formation of micro-thrombi in the lung vessels likely contributes to ventilation/perfusion mismatch and impairs gas exchange.

In this study, we reviewed data from mechanically ventilated patients with SARS-COV-2 severe pneumonia admitted to an intensive care unit (ICU) of Ancona (Italy) in March 2020, who underwent an evaluation of the sublingual microcirculation by means of incident dark field videomicroscopy (Cytocam, Braedius Medical, Amsterdam, NL). The protocol of this retrospective observational study was approved by the local Ethics Committee (Comitato Etico Regionale delle Marche).

*Correspondence: a.donati@univpm.it

†Elisa Damiani and Andrea Carsetti contributed equally to this work Anesthesia and Intensive Care Unit, Department of Biomedical Sciences and Public Health, Università Politecnica delle Marche, via Tronto 10/a, 60126 Ancona, Italy
The Cytocam is a third generation handheld videomicroscope that enables the non-invasive, real-time, in vivo visualization of the microcirculation [3]. This technique is routinely applied in our ICU to monitor microvascular perfusion. Three videos from different sublingual areas were recorded with adequate contrast and focus and without pressure artefacts. The videos were analysed offline with dedicated software (Automated Vascular Analysis 3.2, Microvision Medical, Amsterdam, $\mathrm{NL}$ ) to obtain parameters of vessel density (total vessel density [TVD], perfused vessel density [PVD]) and blood flow quality (microvascular flow index [MFI], percentage of perfused vessels [PPV] and flow heterogeneity index $[\mathrm{HI}])$, as described elsewhere [3].

Data are presented as mean ( \pm standard deviation) or median [1st-3rd quartile], based on the distribution of the variable of interest. The Spearman's rho was calculated to evaluate correlations between variables with a significance level of 0.05 (IBM SPSS Statistics for Windows, Version 21.0. Armonk, NY: IBM Corp).

Among 29 patients with SARS-COV-2 severe pneumonia who were admitted to our ICU during the study period, 12 patients underwent microcirculatory evaluation. Patients' characteristics are reported in Table 1. Microvascular parameters for vessels smaller than $20 \mu \mathrm{m}$ were: TVD 15.3 [14.5-17.1] $\mathrm{mm} / \mathrm{mm}^{2}$; PVD 14.9 [14.116.9] $\mathrm{mm} / \mathrm{mm}^{2}$; PPV 97.3 [95.1-98.8] \%; MFI 2.9 [2.6-3]; HI 0.3 [0-0.4]. D-Dimer levels were inversely correlated with PVD (Spearman rho $=-0.70, p=0.016$ ) and TVD (rho $=-0.645, p=0.032$ ) (Fig. 1). D-Dimer levels were also inversely correlated with $\mathrm{PaO}_{2} / \mathrm{FiO}_{2}$ (rho $=-0.609$, $p=0.047)$. PVD tended to decrease with increasing driving pressure values (rho $=-0.691, p=0.086)$.

\section{Springer Open}

(c) The Author(s) 2020. This article is licensed under a Creative Commons Attribution 4.0 International License, which permits use, sharing, adaptation, distribution and reproduction in any medium or format, as long as you give appropriate credit to the original author(s) and the source, provide a link to the Creative Commons licence, and indicate if changes were made. The images or other third party material in this article are included in the article's Creative Commons licence, unless indicated otherwise in a credit line to the material. If material is not included in the article's Creative Commons licence and your intended use is not permitted by statutory regulation or exceeds the permitted use, you will need to obtain permission directly from the copyright holder. To view a copy of this licence, visit http://creativeco mmons.org/licenses/by/4.0/. 
Table 1 Patients' characteristics

\begin{tabular}{|c|c|}
\hline Male (n, \%) & $10(83.3 \%)$ \\
\hline Age (years) & $56(10)$ \\
\hline BMI $\left(\mathrm{kg} / \mathrm{m}^{2}\right)$ & $31.6(5.4)$ \\
\hline \multicolumn{2}{|l|}{ Comorbidities ( $n, \%)$} \\
\hline Dyslipidemia & $4(33.3 \%)$ \\
\hline Hypertension & $3(25.0 \%)$ \\
\hline Diabetes type 2 & $2(16.7 \%)$ \\
\hline Ischemic cardiomyopathy & $2(16.7 \%)$ \\
\hline Tidal volume (ml) & $421(190)$ \\
\hline RR (breath/min) & $13(3)$ \\
\hline Pplat $\left(\mathrm{cmH}_{2} \mathrm{O}\right)$ & $27(5)$ \\
\hline PEEP $\left(\mathrm{cmH}_{2} \mathrm{O}\right)$ & $10(8.6 ; 13.8)$ \\
\hline$\Delta \mathrm{P}\left(\mathrm{cmH}_{2} \mathrm{O}\right)$ & $13(4)$ \\
\hline Cstat $\left(\mathrm{ml} / \mathrm{cmH}_{2} \mathrm{O}\right)$ & $52(37)$ \\
\hline $\mathrm{FiO}_{2}$ & $0.40(0.35 ; 0.48)$ \\
\hline $\mathrm{PaO}_{2} / \mathrm{FiO}_{2}(\mathrm{mmHg})$ & $207(88)$ \\
\hline VV-ECMO (n, \%) & $6(50.0 \%)$ \\
\hline CRRT $(n, \%)$ & $2(16.7 \%)$ \\
\hline MAP (mmHg) & $88(13)$ \\
\hline HR (beat/min) & $86(23)$ \\
\hline Lactate (mmo/l) & $1.16(0.41)$ \\
\hline $\mathrm{WBC}\left(\times 10^{9} / 1\right)$ & $14.12(5.13)$ \\
\hline IL-6 (pg/ml) & $138(18.5 ; 338)$ \\
\hline D-Dimer (ng/ml) & $788(717 ; 5536)$ \\
\hline \multicolumn{2}{|l|}{ Noradrenaline } \\
\hline$n(\%)$ & $9(75 \%)$ \\
\hline $\mathrm{mcg} / \mathrm{kg} / \mathrm{min}$ & $0.24(0.14)$ \\
\hline \multicolumn{2}{|l|}{ Propofol } \\
\hline$n(\%)$ & $9(75 \%)$ \\
\hline $\mathrm{mg} / \mathrm{kg} / \mathrm{h}$ & $2.5(0.46)$ \\
\hline \multicolumn{2}{|l|}{ Midazolam } \\
\hline$n(\%)$ & $9(75 \%)$ \\
\hline $\mathrm{mg} / \mathrm{kg} / \mathrm{h}$ & $0.26(0.12)$ \\
\hline \multicolumn{2}{|l|}{ Remifentanil } \\
\hline$n(\%)$ & $12(100 \%)$ \\
\hline $\mathrm{mcg} / \mathrm{kg} / \mathrm{min}$ & $0.1(0.85 ; 0.1)$ \\
\hline
\end{tabular}

Data reported as $n$. (\%); mean (standard deviation); median (interquartile range) $B M I$ body mass index, CRRT continuous renal replacement therapy, Cstat static compliance of respiratory system, $\mathrm{FiO}_{2}$ inspiratory fraction of oxygen, $\mathrm{HR}$ heart rate, $\mathrm{IL}-6$ interleukin 6, MAP mean arterial pressure, $\mathrm{PaO}_{2}$ arterial partial pressure of oxygen, $\triangle P$ driving pressure, $P E E P$ positive end expiratory pressure, $P$ plat plateau pressure, $R R$ respiratory rate, $V V$-ECMO veno-venous extracorporeal membrane oxygenation, WBC white blood cells
This is the first study that evaluated microcirculatory blood flow in COVID-19 patients. Microvascular alterations are associated with mortality in critically ill patients [3]. In a general population of 97 critically ill patients, we previously reported a PVD of $19.3 \pm 4.4 \mathrm{~mm} / \mathrm{mm}^{2}$ [3], which seems significantly higher in comparison with the value observed in this sample of COVID-19 patients. Varga et al. recently reported signs of endotheliitis in several organs in patients with SARS-COV-2 infection, suggesting systemic microvascular dysfunction that may account for tissue hypoperfusion, inflammation and a procoagulant state [4].

Sublingual microcirculatory blood flow was significantly compromised in patients with severe influenza A (H1N1) infection [5]. In acute respiratory distress syndrome, increased heterogeneity of sublingual microvascular perfusion was related to an increase in dead-space ventilation, suggesting a role of microcirculatory dysfunction in ventilation/perfusion mismatching [6].

Our report supports a link between coagulopathy and microvascular perfusion disturbances in patients with SARS-COV-2 severe pneumonia. Further studies are needed to demonstrate a cause-effect relationship, clarify the role of microcirculatory disturbances on lung function and indicate potential implications for therapy. 

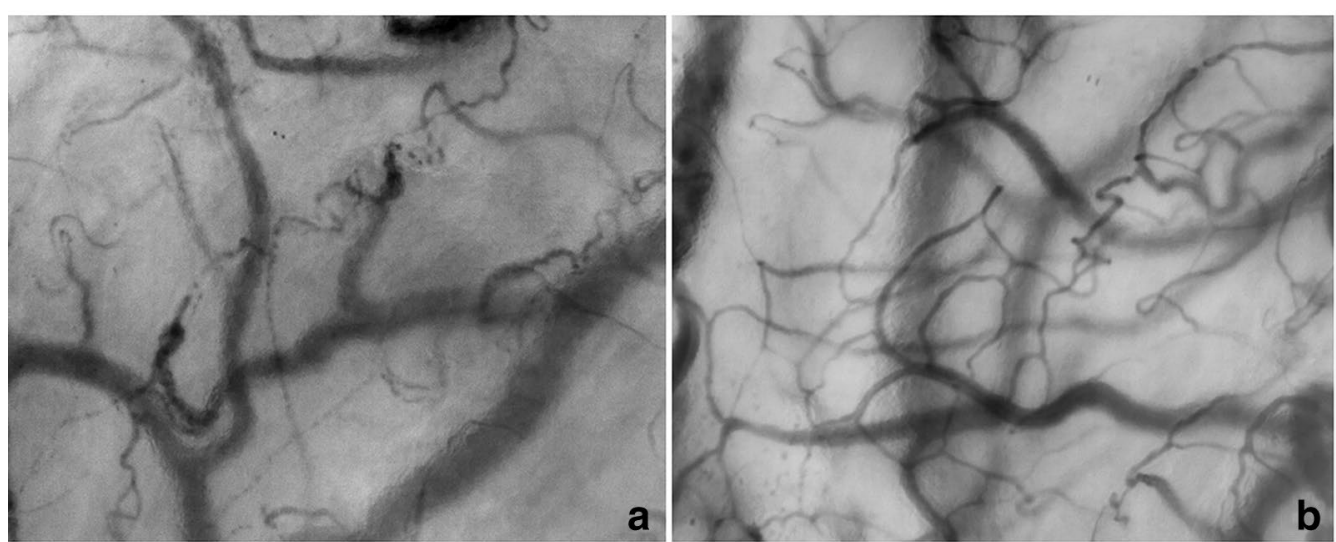

Fig. 1 Sublingual microcirculation of two patients with SARS-COV2 severe pneumonia. Patient (a) showed a significantly lower perfused vessel density as compared to patient (b). D-dimer levels were $6367 \mathrm{ng} / \mathrm{ml}$ in patient (a) and $741 \mathrm{ng} / \mathrm{ml}$ in patient (b). $\mathrm{PaO}_{2} / \mathrm{FiO}_{2}$ ratio was $74 \mathrm{mmHg}$ in patient (a) and $247 \mathrm{mmHg}$ in patient (b)

\section{Abbreviations}

SARS-COV-2: Severe Acute Respiratory Syndrome Coronavirus 2; ACE2: Angiotensin converting enzyme 2; RAS: Renin-angiotensin system; COVID-19: Severe Coronavirus disease 2019; ICU: Intensive care unit; TVD: Total vessel density; PVD: Perfused vessel density; MFI: Microvascular flow index; PPV: Percentage of perfused vessels; HI: Flow heterogeneity index.

\section{Acknowledgements}

We wish to thank the medical and nurse staff of the ICU of Ospedali Riuniti of Ancona for their endless efforts and cooperation for the realization of this study.

\section{Authors' contributions}

ED and AC collected and analysed the data and wrote the manuscript. EC, $\mathrm{CS}, \mathrm{RD}, \mathrm{EA}$ contributed to the interpretation of the data and revised the manuscript critically for important intellectual content. AD designed the study, interpreted the data and revised the manuscript critically for important intellectual content. All authors read and approved the final manuscript.

\section{Funding}

None.

\section{Availability of data and materials}

All data generated or analysed during this study are included in this published article.

\section{Ethics approval and consent to participate}

The protocol of this retrospective observational study was approved by the local Ethics Committee (Comitato Etico Regionale delle Marche, number 2020121). Written informed consent was not requested due to the retrospective study design.

\section{Consent for publication}

Not applicable.

\section{Competing interests}

The authors declare that they have no competing interests.

Received: 24 April 2020 Accepted: 14 May 2020

Published online: 20 May 2020

\section{References}

1. Wevers BA, van der Hoek L. Renin-angiotensin system in human coronavirus pathogenesis. Future Virol. 2010;5(2):145-61.

2. Tang N, Li D, Wang X, Sun Z. Abnormal coagulation parameters are associated with poor prognosis in patients with novel coronavirus pneumonia. J Thromb Haemost. 2020;18(4):844-7.

3. Scorcella C, Damiani E, Domizi R, Pierantozzi S, Tondi S, Carsetti A, et al. MicroDAIMON study: microcirculatory DAlly MONitoring in critically ill patients: a prospective observational study. Ann Intensive Care. 2018;8(1):64.

4. Varga Z, Flammer AJ, Steiger $P$, Haberecker M, Andermatt R, Zinkernagel AS, et al. Endothelial cell infection and endotheliitis in COVID-19. Lancet. 2020. https://doi.org/10.1016/S0140-6736(20)30937-5.

5. Salgado DR, Ortiz JA, Favory R, Creteur J, Vincent JL, De Backer D. Microcirculatory abnormalities in patients with severe influenza $A(H 1 N 1)$ infection. Can J Anaesth. 2010;57(10):940-6.

6. Ospina-Tascón GA, Bautista DF, Madriñán HJ, Valencia JD, Bermúdez WF Quiñones E, et al. Microcirculatory dysfunction and dead-space ventilation in early ARDS: a hypothesis-generating observational study. Ann Intensive Care. 2020;10(1):35.

\section{Publisher's Note}

Springer Nature remains neutral with regard to jurisdictional claims in published maps and institutional affiliations.

\section{Submit your manuscript to a SpringerOpen ${ }^{\circ}$ journal and benefit from:}

- Convenient online submission

- Rigorous peer review

- Open access: articles freely available online

- High visibility within the field

- Retaining the copyright to your article

Submit your next manuscript at $\boldsymbol{\nabla}$ springeropen.com 